\title{
EKSPLORASI NILAI PENDIDIKAN KARAKTER DALAM PETATAH-PETITIH SUNAN GUNUNG JATI
}

\author{
Prabawati Nurhabibah, Hema Widiawati \\ FKIP Universitas Muhammadiyah Cirebon \\ Jl. Fatahillah, Watubelah, Cirebon, Jawa Barat, Indonesia \\ prabawati@umc.ac.id
}

\begin{abstract}
ABSTRAK: Penelitian ini bertujuan mengeksplorasi: (1) nilai-nilai pendidikan karakter yang terdapat dalam petetah-petitih Sunan Gunung Jati; (2) pemanfaatan nilai pendidikan karakter dalam petatah-petitih Sunan Gunug Jati untuk menerbitkan dongeng dan fabel pembentuk karakter positif pada anak. Penelitian ini menggunakan metode deskriptif kualitatif dengan sumber data berupa kumpulan petatah-petitih Sunan Gunung Jati. Terdapat 43 nasihat yang tertulis dalam buku Kesusastraan Cirebon karya Untung Rhardjo. Berdasarkan hasil analisis yang telah dilakukan, peneliti menarik simpulan bahwa (1) semua petatahpetitih Sunan Gunung Jati yang berjumlah 43 memiliki nilai pendidikan karakter yaitu, religius, jujur, toleransi, disiplin, kerja keras, kreatif, mandiri, demokratis, rasa ingin tahu, semangat kebangsaan, cinta tanah air, menghargai prestasi, bersahabat/komunikatif, cinta damai, gemar membaca, peduli lingkungan, peduli sosial, dan tanggung jawab. (2) Nilai-nilai pendidikan karakter dalam petatah-petitih Sunan Gunung Jati dapat dijadikan sebagai materi dalam buku pengayaan berupa kumpulan fabel sebagai pembentuk karakter positif untuk memperkaya imajinasi dan mengembangkan literasi peserta didik.
\end{abstract}

KATA KUNCI: nilai pendidikan karakter; petatah-petitih.

\section{EXPLORATION CHARACTER EDUCATION VALUE IN PETATAH-PETITIH SUNAN GUNUNG JATI}

\begin{abstract}
This research aims to explore: (1) the values of character education contained in the petetahs of Sunan Gunung Jati; (2) utilization of the value of character education in the quotes of Sunan Gunug Jati to publish fairy tales and fables that form positive character in children. This study used a qualitative descriptive method with the data source in the form of a collection of Sunan Gunung Jati slabs. There are 43 pieces of advice written in the book Kesusastraan Cirebon by Untung Rhardjo. Based on the results of the analysis that has been carried out, the researcher concludes that (1) all 43 pieces of Sunan Gunung Jati have character education values, namely, religious, honest, tolerance, discipline, hard work, creative, independent, democratic, curiosity, spirit of nationality, love of the country, respect for achievement, friendly/ communicative, love peace, love to read, care for the environment, care for social, and responsibility. (2) The values of character education in the quotes of Sunan Gunung Jati can be used as material in an enrichment book in the form of a collection of fables as positive character builders to enrich the imagination and develop literacy of students.
\end{abstract}

KEYWORDS: character education value; petatah-petitih.

\begin{tabular}{llll}
\hline Diterima: & Direvisi: & Disetujui: & Dipublikasi: \\
2020-12-04 & - & $2020-12-06$ & $2021-03-28$
\end{tabular}

Pustaka : Nurhabibah, P., \& Widiawati, H. (2021). EKSPLORASI NILAI PENDIDIKAN KARAKTER DALAM PETATAH-PETITIH SUNAN GUNUNG JATI. Fon : Jurnal Pendidikan Bahasa dan Sastra Indonesia, 17(1), 52-64. doi:https://doi.org/10.25134/fjpbsi.v17i1.3729

\section{PENDAHULUAN}

Pendidikan adalah suatu usaha manusia untuk membina kepribadiannya sesuai dengan nilai yang berlaku di masyarakat. Proses pendidikan bahkan juga terjadi dalam lingkup masyarakat yang sederhana sekalipun (Ramayulis, 2008, Hlm. 166). Esensi pendidikan adalah seperangkat bimbingan dan pengarahan dalam kehidupan manusia yang berbentuk kemampuan dasar dan kemampuan ajar yang mengubah kepribadiannya sebagai makhluk sosial (Arifin, 1994, Hlm. 14).

Sastra merupakan salah satu alat pendidikan untuk menghaluskan rasa, memupuk simpati, dan menggugah empati. Ada beragam jenis karya sastra 
yang disuguhkan dalam beragam khasanah di Indonesia, baik secara tertulis maupun secara lisan. Folklor, sastra lisan, dan mitos merupakan warisan turuntemurun yang senantiasa memberikan nilai pendidikan dan nilai budaya bagi generasi muda untuk mempertahankan jati diri daerah dan budayanya.

Menurut Rafiek (2010, Hlm. 57) sastra lisan dapat bertahan secara turuntemurun karena sifatnya yang lentur, tidak $\mathrm{kaku}$, dan penyajiannya berlainan dengan sastra tertulis yang acapkali sudah dibatasi oleh acuan tertentu. Misalnya aturan penulisan. Sastra lisan mempunyai ciriciri gaya bahasa yang berlainan dengan sastra yang tertulis walaupun perbedaan itu tidak begitu mencolok. Ciri-ciri khas yang berwujud pengungkapan alam pikiran masyarakat, norma hidup, nilainilai, tercakup dalam sastra lisan, seperti sering tergambar pula dalam sastra tertulis.

Keberadaan jenis karya sastra yang berkembang di Cirebon yaitu berbentuk sastra tulis dan sastra lisan. Sastra tulisan terdiri dari kakawen, kidung, macapat, wangsalan, parikan, pribasa, sanepa, ukara sesumbar, perlambang, sasmita, basa prenesan, basa rinengga, sandi sastra, panyandra, dan geguritan. Sedangkan sastra lisan hanya terdiri dari dua jenis yaitu jawokan dan gugon tuwon.

Sastra lisan di Cirebon tidak banyak ragamnya, di antaranya jawokan dan gugon tuwon. Sastra lisan yang cukup menarik dan pantas menjadi sorotan adalah gugon tuwon yang berasal dari petatah-petitih dari Sunan Gunung Jati. Gugon tuwon merupakan tradisi yang memiliki dua pengertian, yaitu memiliki makna sesungguhnya atau makna harfiah, kedua memiliki arti kiasan atau fungsi estetis. Gugon tuwon menurut Rahardjo (2005, Hlm. 29) secara etimologis berasal dari kata gugu dan tuwa. Gugu artinya ditaati, diikuti, sedangkan tuwa adalah orang tua. Gugu diberi panambang an dan menjadi gugon, begitupun tuwa diberi panambang an menjadi tuwon. Gugon tuwon merupakan sebuah kalimat yang tersusun dari beberapa kata yang mengandung nasehat, mengajarkan tentang hidup dan perilaku yang semestinya dimiliki oleh setiap manusia.

Suatu nasihat memiliki hubungan erat dengan penanaman pendidikan karakter pada anak. Hal ini sejalan dengan pendapat Syarbini (2013, Hlm. 85) bahwa nasihat berasal dari kata "nash" yang artinya halus, murni dan bersih yang merupakan lawan kata dari kotor dan curang. Dengan demikian kata-kata nasihat harus jauh dari kecurangan dan kata-kata kotor tetapi haruslah kata-kata bersih atau lemah lembut. Maka nasehat adalah sebuah kalimat yang mengungkapkan suatu bentuk keinginan kebaikan kepada objek yang diberikan nasihat. Metode nasihat adalah penyampaian kata-kata yang menyentuh hati dan disertai keteladanan.

Penelitian terdahulu tentang petatah petitih dilakukan di berbagai daerah sebagai penelitian yang memuat kearipan lokal. Penelitian-penelitian hanya menemukan dua penelitian tentang petatah-petitih oleh Munir (2013) berjudul Nilai-Nilai Pendidikan dalam Petatah Petitih Adat Minangkabau (Alternatif Membangun Pendidikan Berkarakter) dan Kistoro dan Sibarani (2020) berjudul Relevansi Konsep Nilai Petatah Petitih Sunan Gunung Djati dalam Pendidikan Islam. LE Pradita dkk. (2019)berjudul Traditional Expressions As a Reflection of Cirebon Socio-Cultural Life: A Case Study of Petatah-petitih Sunan Gunung Jati.

Penelitian Munir sudah lama dan berada di Minangkabau dan penelitian kedua dari Kristono \& Sibani merupakan penelitian yang hanmpir sama namun fokus pembahasannya pada cara pengajaran islam yang dilakukan oleh Sunan Gunung Jati. Pada penelitian 
ketiga dari Pradita dkk. mengungkapkan tradisi sosial. Adanya jarak dari penelitian-penelitian tersebut membuat penulis menginginkan penelitian berkaitan dengan Pendidikan karakter yang pada masa modern ini dibutuhkan dalam dunia pendidikan.

Penelitian tentang pendidikan karakter juga sudah banyak dilakukan seperti penelitian Fajarini (2014) mengemukakan dalam teorinya bahwa pendidikan karakter adalah suatu proses dari bangsa yang mempersiapkan masa mudanya dan erat kaitannya dengan masyarakat lokal. Penelitian lain tentang pendidikan karakter dan kearipan lokal dituliskan oleh Ruyadi (2010) berjudul MODEL PENDIDIKAN KARAKTER BERBASIS KEARIFAN BUDAYA LOKAL (Penelitian Terhadap Masyarakat Adat Kampung Benda Kerep Cirebon Provinsi Jawa Barat Untuk Pengembangan Pendidikan Karakter Di Sekolah). Asriati (2012) Berjudul Mengembangkan Karakter Peserta Didik Berbasis Kearifan Lokal Melalui Pembelajaran di Sekolah. Mumpuni (2013) Berjudul Potensi Pendidikan Keunggulan Lokal Berbasis Karakter Dalam Pembelajaran Biologi Di Indonesia. Yunus (2013) berjdul Transformasi Nilai-Nilai Budaya Lokal Sebagai Upaya Pembangunan Karakter Bangsa.

Berawal dari pemikiran inilah, penelitian ini dilakukan sebagai upaya untuk mengangkat nilai-nilai pendidikan karakkter yang terdapat dalam petatahpetitih Sunan Gunung Jati. Nilai-nilai pendidikan karakter tersebut nantinya akan menjadi bahan untu memperkaya literasi pembentuk karakter positif pada anak utamanya peserta didik di kelas II SD. Berdasarkan latar belakang tersebut, penelitian ini bertujuan untuk mendesksripsikan dan menjelaskan: (1) nilai-nilai pendidikan karakter yang terdapat dalam petatah-petitih Sunan Gunung Jati, dan (2) pemanfaatan nilai pendidikan karakter dalam petatah-petitih Sunan Gunug Jati untuk menerbitkan dongeng dan fabel pembentuk karakter positif pada anak sebagai buku pengayaan dalam pembelajaran apresiasi dongeng dan fabel di kelas II SD.

\section{METODE}

Penelitian ini menggunakan metode deskriptif kualitatif dengan teknik analisis data kualitatif yang bersifat induktif. Menurut teori Sutopo (2006) kajian ini dilakukan tidak dalam rangka membuktikan hipotesis, tetapi menarik simpulan berdasarkan hasil analisis data yang dilakukan. Sumber data penelitian diambil dari buku Kesusastraan Cirebon karya Untung Rahardjo yang diterbitkan pada tahun 2005. Ada 43 petatah-petitih yang menjadi populasi dalam kajian ini. Dari 43 petetah-petitih yang ada, dipilih 9 petatah-petitih secara purposive sampling. kesembilan petatah-petitih tersebut dipilih berdasarkan kecenderungan tematik yang diangkat dengan mengedepankan empat pilar nilai pendidikan karakter yang ada dalam nasihat Sunan Gunung Jati. Keempat pilar nilai pendidikan karakter sebut adalah penguatan agama, penguatan sosial budaya, penguatan nilai pancasila, dan penguatan tujuan pendidikan nasioanl. Petatah-petitih tersebut dianalisis secara interpretatif dengan melandaskan pada makna dan nilai pendidikan. Hasilnya disajikan dalam bentuk analisis deskriptif. Selain itu, hasil yang diperoleh melalui analisis juga dijustifikasi dengan hasil wawancara dengan tokoh budayawan dan guru untuk melihat keterkaitan hasil kajian dengan pembuatan kumpulan fabel pembentuk karakter positif pada anak.

HASIL DAN PEMBAHASAN

Analisis Nilai Pendidikan Karakter dalam Petatah-Petitih Sunan Gunung Jati 


\begin{tabular}{|c|c|c|c|c|}
\hline & & & sendiri & \\
\hline 13 & $\begin{array}{l}\text { Aja ilok ngijek } \\
\text { rarahi wong }\end{array}$ & $\begin{array}{l}\text { Jangan sering menginjak } \\
\text { muka orang }\end{array}$ & $\begin{array}{l}\text { jangan suka menghina orang } \\
\text { lain }\end{array}$ & Toleransi \\
\hline 14 & $\begin{array}{l}\text { Kenane ing hajate } \\
\text { wong }\end{array}$ & $\begin{array}{l}\text { Kabulkanlah keinginan } \\
\text { orang }\end{array}$ & $\begin{array}{l}\text { bantulah seseorang sekiranya } \\
\text { kita mampu }\end{array}$ & Peduli Sosial \\
\hline 15 & $\begin{array}{l}\text { Angadohna ing } \\
\text { perpadu }\end{array}$ & Jauhi perselisihan & $\begin{array}{lr}\text { Dalam menyelesaikan suatu } \\
\text { masalah } & \text { senantiasalah } \\
\text { bermusyawarah } & \end{array}$ & Demokratis \\
\hline 16 & $\begin{array}{l}\text { Aja ujub riya suma } \\
\text { takabur }\end{array}$ & $\begin{array}{l}\text { jangan pernah } \\
\text { sombong, terlebih lagi } \\
\text { takabur }\end{array}$ & $\begin{array}{l}\text { Dalam hidup kita harus } \\
\text { bersikap tawadu }\end{array}$ & Religius \\
\hline 17 & $\begin{array}{l}\text { Aja duwe ati } \\
\text { nguneg }\end{array}$ & $\begin{array}{l}\text { Jangan punya hati yang } \\
\text { suka berkeluh kesah }\end{array}$ & $\begin{array}{l}\text { Segala cobaan harus kita } \\
\text { terima dengan lapangdada, } \\
\text { tanpa banyak mengeluh }\end{array}$ & $\begin{array}{l}\text { Menghargai } \\
\text { Prestasi }\end{array}$ \\
\hline 18 & $\begin{array}{l}\text { Den hormat ing } \\
\text { wong tua }\end{array}$ & Hormatilah orang tua & $\begin{array}{lccc}\text { Selama } & \text { hidup } & \text { kita } & \text { harus } \\
\text { berbakti } & \text { kepada } & \text { kedua } & \text { orang } \\
\text { tua kita } & & & \\
\end{array}$ & Religius \\
\hline 19 & $\begin{array}{l}\text { Aja lunga layaran } \\
\text { ing lautan }\end{array}$ & $\begin{array}{l}\text { Jangan pergi berlayar } \\
\text { ketengah lautan }\end{array}$ & $\begin{array}{l}\text { jangan pernah bertindak } \\
\text { sesuatu tanpa mempersiapkan } \\
\text { segala resikonya }\end{array}$ & $\begin{array}{l}\text { Tanggung } \\
\text { Jawab }\end{array}$ \\
\hline 20 & $\begin{array}{l}\text { Amepesa ing bina } \\
\text { batan }\end{array}$ & $\begin{array}{l}\text { Musnahkanlah bentuk } \\
\text { yang lebih besar }\end{array}$ & $\begin{array}{l}\text { Jangan suka berangasan atau } \\
\text { serakah dalam hidup }\end{array}$ & Jujur \\
\hline 21 & $\begin{array}{l}\text { Aja nyidra jangji } \\
\text { mubarang }\end{array}$ & $\begin{array}{l}\text { jangan pernah } \\
\text { mengingkari janji }\end{array}$ & $\begin{array}{l}\text { Jangan pernah mengingkari } \\
\text { janji, sebab salah satu ciri dari } \\
\text { orang munafik apabila ia } \\
\text { berjanji ia ingkar }\end{array}$ & $\begin{array}{l}\text { Tanggung } \\
\text { Jawab }\end{array}$ \\
\hline 22 & $\begin{array}{l}\text { Aja ilok ngamad } \\
\text { kang durung yakin }\end{array}$ & $\begin{array}{l}\text { Jangan suka menduga } \\
\text { jika belum yakin benar }\end{array}$ & $\begin{array}{l}\text { Jangan suka memvonis sesuatu } \\
\text { yang belum terbukti } \\
\text { kebenarannya }\end{array}$ & Demokratis \\
\hline 23 & $\begin{array}{l}\text { Aja ilok gawe } \\
\text { bobad }\end{array}$ & Jangan suka berdusta & $\begin{array}{l}\text { Jangan suka berdusta, sebab } \\
\text { salah satu ciri dari orang } \\
\text { munafik apabila ia berkata } \\
\text { dusta }\end{array}$ & Jujur \\
\hline 24 & $\begin{array}{l}\text { Pemboraban kang } \\
\text { ora patut anulungi }\end{array}$ & $\begin{array}{l}\text { Jangan pernah menolong } \\
\text { yang tidak patut } \\
\text { ditolongi }\end{array}$ & $\begin{array}{l}\text { Jangan pernah memberi } \\
\text { pertolongan untuk } \\
\text { tindakan tercela }\end{array}$ & Demokratis \\
\hline 25 & $\begin{array}{l}\text { Aja ngaji kejayaan } \\
\text { kang ala rautah }\end{array}$ & $\begin{array}{l}\text { Jangan mengaji } \text { ilmu } \\
\text { kanuragan yang tidak } \\
\text { baik }\end{array}$ & $\begin{array}{l}\text { Jangan belajar sesuatu yang } \\
\text { tidak benar atau } \\
\text { menyalahgunakan suatu ilmu }\end{array}$ & $\begin{array}{l}\text { Gemar } \\
\text { Membaca }\end{array}$ \\
\hline 26 & $\begin{array}{l}\text { Ing panemu aja } \\
\text { gawe tingkah }\end{array}$ & $\begin{array}{l}\text { Bila pandai jangan } \\
\text { berlagak }\end{array}$ & $\begin{array}{l}\text { Apabila kita memiliki suatu } \\
\text { kepandaian hendaknya ia tidak } \\
\text { boleh sombong }\end{array}$ & $\begin{array}{l}\text { Bersahabat/ } \\
\text { Komunikatif }\end{array}$ \\
\hline
\end{tabular}


FKIP Universitas Kuningan

\begin{tabular}{llll}
\hline 27 & $\begin{array}{l}\text { Aja dahar yen } \\
\text { durung ngeli }\end{array}$ & Jangan makan sebelum & Meneladani perilaku Nabi Religius \\
& lapar & Muhammad SAW, yang tidak \\
& & pernah makan sebelum beliau \\
& benar-benar merasa lapar
\end{tabular}

\begin{tabular}{|c|c|c|}
\hline 28 & $\begin{array}{l}\text { Aja nginum yen } \\
\text { durung ngelok }\end{array}$ & $\begin{array}{l}\text { Jangan minum sebelum } \\
\text { haus }\end{array}$ \\
\hline 29 & $\begin{array}{l}\text { Aja turu } \begin{array}{r}\text { yen } \\
\text { durung } \\
\text { arip }\end{array} \\
\text { ketekan }\end{array}$ & $\begin{array}{l}\text { Jangan tidur sebelum } \\
\text { mengantuk }\end{array}$ \\
\hline
\end{tabular}

Meneladani perilaku Nabi Religius

Muhammad SAW, yang tidak pernah minum sebelum beliau betul-betul merasa haus

\begin{tabular}{|c|c|c|c|c|}
\hline 30 & Yen kaya den luhur & Jika kaya di atas & $\begin{array}{l}\text { Bila kaya harus dermawan, } \\
\text { sesuai dengan hadist Nabi } \\
\text { "tangan di atas lebih mulia } \\
\text { daripada tangan yang di bawah }\end{array}$ & Peduli Sosial \\
\hline 31 & Angasaha diri & Asahlah diri & Selalu bermawas diri & $\begin{array}{l}\text { Rasa Ingin } \\
\text { Tahu }\end{array}$ \\
\hline 32 & $\begin{array}{l}\text { Tepo saliro den } \\
\text { adol }\end{array}$ & $\begin{array}{l}\text { Menghargai diri yang } \\
\text { dijual }\end{array}$ & $\begin{array}{l}\text { Hendaklah perbuatan baik dan } \\
\text { menghargai orang lain yang } \\
\text { diutamakan }\end{array}$ & $\begin{array}{l}\text { Semangat } \\
\text { Kebangsaan }\end{array}$ \\
\hline 33 & $\begin{array}{l}\text { Ngoletan rejeki } \\
\text { kang halal }\end{array}$ & carilah rezeki yang halal & $\begin{array}{l}\text { carilah rezeki dengan cara dan } \\
\text { sumber yang halal }\end{array}$ & Kerja Keras \\
\hline 34 & $\begin{array}{l}\text { Aja akeh kang den } \\
\text { pamrih }\end{array}$ & Jangan banyak pamrih & $\begin{array}{l}\text { Jika berbuat sesuatu jangan } \\
\text { terlalu banyak berharap akan } \\
\text { balasan dari perbuatan itu }\end{array}$ & $\begin{array}{l}\text { Semangat } \\
\text { Kebangsaan }\end{array}$ \\
\hline 35 & $\begin{array}{l}\text { Den dhuka weman } \\
\text { lan suka mamberih } \\
\text { gelis lipur }\end{array}$ & $\begin{array}{l}\text { Kala berduka jangan } \\
\text { ditampakan supaya lekas } \\
\text { hilang }\end{array}$ & $\begin{array}{l}\text { Saat ditimpa } \\
\text { hendaknya jangan ditampakan } \\
\text { agar kesusahan itu segera } \\
\text { hilang }\end{array}$ & Mandiri \\
\hline 36 & $\begin{array}{l}\text { Aja ilok gawe lara } \\
\text { ati ing wong }\end{array}$ & $\begin{array}{l}\text { Jangan suka menyakiti } \\
\text { hati orang lain }\end{array}$ & $\begin{array}{l}\text { jangan suka menyakiti hati } \\
\text { orang lain }\end{array}$ & $\begin{array}{l}\text { Bersahabat/ } \\
\text { Komunikatif }\end{array}$ \\
\hline 37 & $\begin{array}{l}\text { Ake lara ati ing, } \\
\text { namung saking } \\
\text { duriat }\end{array}$ & $\begin{array}{l}\text { Hati sering disakiti orang } \\
\text { cuma karena asal-usul }\end{array}$ & $\begin{array}{l}\text { Walaupun hati sering disakiti } \\
\text { oleh orang lain karena derajat } \\
\text { dan asal usul kita (dihina), } \\
\text { hendaklah selalu membalasnya } \\
\text { dengan kebaikan bukannya } \\
\text { membalas lagi kejahatannya }\end{array}$ & Cinta Damai \\
\hline 38 & $\begin{array}{l}\text { Aja ngagungakeen } \\
\text { ing salira }\end{array}$ & $\begin{array}{l}\text { Jangan pernah } \\
\text { membanggakan diri }\end{array}$ & Tidak boleh sombong & Religius \\
\hline 39 & $\begin{array}{lr}\text { Aja } & \text { anglakoni } \\
\text { lunga } & \text { haji ing } \\
\text { mekah } & \end{array}$ & $\begin{array}{l}\text { Jangan melakukan pergi } \\
\text { haji ke mekah }\end{array}$ & $\begin{array}{l}\text { Jangan pernah berangkat } \\
\text { ziarah ketanah suci apabila } \\
\text { secara moril maupun materil } \\
\text { belum mencukupi }\end{array}$ & Kerja Keras \\
\hline 40 & $\begin{array}{l}\text { Aja munggah ning } \\
\text { gunung gedhe }\end{array}$ & $\begin{array}{l}\text { Jangan mendaki gunung } \\
\text { yang tinggi atau masuk }\end{array}$ & $\begin{array}{l}\text { Jangan melakuakan suatu } \\
\text { pekerjaan tanpa persiapan atau }\end{array}$ & Tanggung \\
\hline
\end{tabular}

Meneladani prilaku Nabi Religius

Muhammad SAW, yang tidak pernah tidur sebelum beliau benar-benar mengantuk 
FKIP Universitas Kuningan

\begin{tabular}{lllll}
\hline \multicolumn{1}{c}{ utawa manjing } \\
ning kawah
\end{tabular}

Sunan Gunung Jati atau Syarif Hidayatullah adalah satu-satunya Wali yang menyebarkan agama Islam di Jawa barat. Sunan Gunung Jati dilahirkan Tahun 1448 Masehi. Ayahnya adalah Syarif Abdullah bin Nur Alam bin Jamaluddin Akbar, seorang Mubaligh dan Musafir besar dari Gujarat, India yang sangat dikenal sebagai Syekh Maulana Akbar bagi kaum Sufi di tanah air. Syekh Maulana Akbar adalah putra Ahmad Jalal Syah putra Abdullah Khan putra Abdul Malik putra Alwi putra Syekh Muhammad Shahib Mirbath, ulama besar di Hadramaut, Yaman yang silsilahnya sampai kepada Rasulullah melalui cucunya Imam Husain. Sedangkan Ibu Sunan Gunung Jati adalah Nyai Rara Santang (Syarifah Muda'im) yaitu putri dari Sri Baduga Maharaja Prabu Siliwangi dari Nyai Subang Larang, dan merupakan adik dari Kian Santang atau Pangeran Walangsungsang yang bergelar Cakrabuwana/ Cakrabumi atau Mbah Kuwu Cirebon Girang yang berguru kepada Syekh Datuk Kahfi, seorang Muballigh asal Baghdad bernama asli
Idhafi Mahdi bin Ahmad (Urrohman, 2009, Hlm. 162).

Dalam menyebarkan agama islam di Tanah Jawa, Sunan Gunung Jati tidak bekerja sendirian, beliau sering ikut bermusyawarah dengan anggota wali lainnya di Masjid Demak. Bahkan disebutkan beliau juga membantu berdrinya Masjid Demak. Dari pergaulannya dengan Sultan Demak dan para Wali lainnya ini akhirnya Syarif Hidayatullah mendirikan Kesultanan Pakungwati di Cirebon dan ia memproklamirkan diri sebagai Raja yang pertama dengan gelar Sultan. Pada era Syarif Hidayatullah atau lebih dikenal dengan gelar Sunan Gunung Jati dapat dikatakan sebagai era keemasan (Golden Age) perkembangan Islam di Cirebon. Sebelum Syarif Hidayatullah, Cirebon dipimpin oleh Pangeran Cakrabuana (1447-1479) merupakan rintisan pemerintahan berdasarkan asas Islam, dan setelah Syarif Hidayatullah, pengaruh para penguasa Cirebon masih berlindung di balik kebesaran nama Syarif 
Hidayatullah (Mastuki dan El-saha, 2003, Hlm. 21-34).

Menurut Rahardjo (2005, Hlm. 2935) tercatat Sunan Gunung Jati pernah memberikan wasiat yang biasa disebut wasiat Jeng Sunan Jati. Wasiat ini menurut sumber diwejangkan kepada Syekh Malaya atau Sunan Kalijaga. Dilihat dari segi bentuk serta isi sesungguhnya wasiat tersebut termasuk ke dalam Gugon Tuwon. Wasiat itu terdiri dari: Yen sembahyang kungsiya pucuke panah, yen puasa den kungsi tetaling gundewa, den welas asih ing pepada, mulyakena ing tetamu, gugunen sifat kang pinuji, den bisa megenging nafsu, manah den sukur ing Allah, ilbadah kang tetep, kudu ngakehaken pertobat, singkirna sifat kang den wanci, duweha sifat kang wanti, wedia ing Allah lan ingsun, aja ilok ngijek rarahi wong, kenane ing hajate wong, angadohna ing perpadu, aja ujub riya suma takabur, aja duwe ati nguneg, den hormat ing wong tuwa, aja lunga layaran lautan, amepesa ing bina batan, aja nyidra jangji mubarang, aja ilok ngamad kang durung yakin, aja ilok gawe bobad, pemboraban kang ora patut anulungi, aja ngaji kejayaan kang ala rautah ing panemu aja gawe tingkah, aja dahar yen durung ngeli, aja nginum yen durung ngelok, ja turu yen durung ketaken arip, yen kaya den luhur, angsana diri, tepo seliro den adol, ngoletan rejeki kang halal, aja akeh kang den pamrih, den dhuka weman lan suka mamberih gelis lipur, aja ilok gawa lara ati ing wong, ake lara ati ing wong, namung saking duriat, aja ngagungaken ing salira, aja anglakoni lunga haji ing Mekah, aja munggah ning gunung gedhe utawa manjing ning kawah, aja ngimami utawa khotbah ing mesjid Agung, aja dagangan utawa warungan, Ingsun titip tajug lan fakir miskin.

Secara teoretis pendidikan karakter adalah sebuah usaha sadar menanamkan nilai-nilai moral dan akhlak mulia yang dilakukan oleh pendidik dan orang tua guna membentuk pribadi anak (peserta didik) agar menjadi manusia yang baik. Pendidikan karater pada intinya bertujuan membentuk bangsa yang tangguh, kompetitif, berakhlak mulai, bermoral, bertoleran, bergotong royong, berjiwa patriotik, berkembang dinamis, berorientasi ilmu pengetahuan dan teknologi yang semuanya dijiwai oleh iman dan takwa kepada Tuhan yang Maha Esa berdasarkan Pancasila (Narwanti, 2014, Hlm. 16).

Ada delapan belas muatan pendidikan karakter yang terintegrasi dalam kurikulum pendidikan di sekolah, di antaranya adalah: (1) Religius, yaitu sikap dan perilaku yang patuh dalam melaksanakan ajaran agama yang dianutnya, toleran terhadap pelaksanaan ibadah agama lain, hidup rukun dengan pemeluk agama lain. (2) Jujur, yaitu perilaku yang didasarkan pada upaya menjadikan dirinya sebagai orang yang selalu dapat dipercaya dalam perkataan, tindakan, dan pekerjaan. (3) Toleransi, yaitu sikap dan tindakan menghargai perbedaan agama, sukum etnis, pendapat, sikap dan tindakan orang lain yang berbeda dari dirinya. (4) Disiplin, yaitu tindakan yang menunjukkan perilaku tertib dan patuh pada berbagai ketentuan dan peraturan. (5) Kerja keras, yaitu sikap bersungguh-sungguh tanpa mengenal lelah atau berhenti sebelum target kerja tercapai dan selalu mengutamakan atau memperhatikan kepuasan hasil pada setiap kegiatan yang dilakukan. (6) Kreatif, yaitu berpikir dan melakukan sesuatu untuk menghasilkan cara atau hasil baru dari sesuatu yang telah dimiliki. (7) Mandiri, yaitu sikap dan perilaku yang tidak mudah tergantung pada orang lain dalam menyelesaikan tugas-tugas. (8) Demokratis, yaitu cara berpikir, bersikap, dan bertindak yang menilai sama hak dan kewajiban dirinya dan orang lain. (9) Rasa Ingin Tahu, yaitu sikap dan tindakan yang selalu berupaya 
untuk mengetahui lebih mendalam dan meluas dari sesuatu yang dipelajarinya, dilihat, dan didengar. (10) Semangat Kebangsaan, yaitu cara berpikir, bertindak, dan berwawasan yang menempatkan kepentingan bangsa dan negara di atas kepentingan diri dan kelompoknya. (11) Cinta Tanah Air, yaitu mencintai bangsa sendiri, yakni munculnya perasaan mencintai oleh warga negara untuk negaranya dengan sedia mengabdi, berkorban, memelihara persatuan dan kesatuan, melindungi tanah airnya dari segala ancaman, gangguan dan tantangan yang dihadapi oleh negaranya. (12) Menghargai Prestasi, yaitu sikap dan tindakan yang mendorong dirinya untuk menghasilkan sesuatu yang berguna bagi masyarakat, dan mengakui, serta menghormati keberhasilan orang lain. (13) Bersahabat/ Komunikatif, yaitu tindakan yang memperlihatkan rasa senang berbicara, bergaul, dan bekerja sama dengan orang lain. (14) Cinta Damai, yaitu sikap, perkataan, dan tindakan yang menyebabkan orang lain merasa senang dan aman atas kehadiran dirinya. (15) Gemar Membaca, yaitu ebiasaan menyediakan waktu untuk membaca berbagai bacaan yang memberikan kebajian bagi diirnya. (16) Peduli Lingkungan, yaitu sikap dan tindakan yang selalu berupaya mencegah kerusakan pada lingkungan alam di sekitarnya, dan mengembangkan upaya-upaya untuk memperbaiki. (17) Peduli Sosial, yaitu sikap dan tindakan yang selalu ingin memberi bantuan pada orang lain dan masyarakat yang membutuhkan. (18) Tanggung Jawab, yaitu sikap dan perilkau seseorang utnuk melaksanakan tugas dan kewajibannya, yang seharusnya dia lakukan, terhadap diri sendiri, masyarakat, lingkungan (alam, sosial dan budaya), negara dan Tuhan Yang Maha Esa.

\section{Eksplorasi Nilai Pendidikan Karakater dalam Petatah-Petitih Sunan Gunung Jati}

Petatah-petitih merupakan salah satu sastra lisan masyarakat yang berisikan nasihat, sindirian, pandangan-pandangan atau pedoman hidup yang baik, dan petunjuk-petunjuk dalam melakukan hubungan sosial dalam masyarakat. Sunan Gunung Jati adalah seorang Wali dengan lata belakang keislaman yang kuat. Nasihat-nasihat yang diungkapkan tidak jauh dari unsur religiusitas. Nilai-nilai keagamaan inilah yang dijadikan pedoman menanamkan pendidikan karakter pada anak. Ada empat pilar pendidikan karakter yang terhimpun dalam kumpulan petatahpetitih ini, yaitu: penguatan nilai agama, sosial budaya, pancasila dan tujuan pendidikan nasional. Dari keempat pilar ini, dipilih sembilan petatah-petitih yang mewakili untuk dianalisis.

\section{Nilai Agama}

Nilai pendidikan karakter yang paling mendominasi dari keseluruhan petatahpetitih Sunan Gunung Jati adalah nilai religius. Menurut Sjarkawi (31) Nilai religius adalah nilai yang bersumber dari keyakinan ketuhanan yang ada pada diri seseorang. Dengan demikian nilai religius ialah sesuatu yang berguna dan dilakukan oleh manusia, berupa sikap dan perilaku yang patuh dalam melaksanakan ajaran agama yang dianutnya dalam kehidupan sehair-hari. Nilai-nilai pokok dalam ajaran Islam yang harus ditanamkan dan dikembangkan pada anak sejak usia dini menurut Nata (2011, Hlm. 125) antara lain: iman, ibadah, dan akhlak. Nilai religius dapat ditemukan pada beberapa kutipan petatah-petitih berikut.

Yen sembahyang kungsiya pucuke panah

Nasihat Yen sembahyang kungsiya pucuke panah sangat kental dengan nilai religius yang berhubungan dengan keimanan. Umat manusia diingatkan untuk khusyu dan tuma'nina dalam 
melaksanakan ibadah sholat, karena sholat merupakan tiang agama. Karena itu, tidak akan tegak agama seseorang yang meninggalkan shalat dan ia tidak akan mendaoatkan bagian dalam agama ini. Menegakkan shalat adalah suatu bentuk keimanan dan meninggalkannya merupakan kekufuran. Maka, siapa yang menjaga shalatnya, maka hatinya akan bercahaya, demikian pula wajah dan kuburnya, dan saat dikumpulkam di Mahsyar, ia juga akan mendapat keselamatan pada hari kiamat.

\section{Gugunen sifat kang pinuji}

Seseorang yang beriman kepada Rasulullah Muhammad Saw tentu akan meneladani perilaku Rasul Saw. dalam kehidupan sehari-hari. Di mulai dari ucapan, perbuatan, dan tingkah laku. Semua hal yang baik dari Rasulullah Muhammad Saw. menjadi teladan. Nabi Muhammad Saw. Merupakan manusia paling mulia di dunia ini, segala tingkah laku dan kehidupan menjadi teladan seluruh manusia yang beragama Islam di bumi ini. Agama lain juga mengakui bahwa Nabi Muhammad saw. adalah manusia yang mendekati paling sempurna. Manah den sukur ing Allah

Syukur dengan hati dilakukan dengan menyadari sepenuhnya bahwa nikmat yang diperoleh adalah sematamata karena anugerah dan kemurahan Ilahi. Syukur dengan hati mengantar manusia untuk menerima anugerah dengan penuh kerelaan tanpa menggerutu dan keberatan betapapun kecilnya nikmat tersebut. Syukur ini juga mengharuskan yang bersyukur menyadari betapa besar kemurahan, dan kasih sayang Ilahi sehingga terlontar dari lidahnya pujian kepada-Nya. Qarun yang mengingkari keberhasilannya atas bantuan Ilahi, dan menegaskan bahwa itu diperolehnya semata-mata karena kemampuannya, dinilai oleh Al-Quran sebagai kafir atau tidak mensyukuri nikmat-Nya.

Wedia ing Allah lan ingsun
Rasa takut kepada Allah adalah sifat seorang yang bertakwa. Bahkan, hal tersebut merupakan bukti keimanan mereka kepada Alla Ta'ala. Allah telah sifati hamba-hambanya yang mulia, yaitu para Nabi `alaihimus salam, sebagai orang-orang yang senantiasa berdoa dengan rasa harap dan takut. Takut kepada Allah memiliki peran yang sangat penting dalam kehidupan sehari-hari. Seseorang yang takut kepada Allah SWT., tentu dapat menjaga semua ucapan dan tindakannya dari perbuatan tercela. Selain itu, orang yang takut kepada Allah SWT juga akan mendapatkan berbagai manfaat dan keuntungan dalam hidupnya, antara lain sebagai berikut: mampu menjaga tutur kata dan perbuatannya dari perilaku maksiat yang dilarang oleh Allah, semakin hari bertambah rajin ibadahnya dan amal kebaikannya, tampak berani menghadapi setiap rintangan, sepanjang untuk membela kebenaran, sebab dalam hatinya tidak ada rasa takut selain hanya kepada Allah SWT, jika disebutkan nama Allah, hatinya bergetar dan jiwanya tunduk khusyuk mengagungkan nama-Nya, senantiasa menjauhi dan menghindari perbuatan yang dilarang oleh Allah SWT. Semakin seseorang berilmu tentang Allah Ta `ala, semakin besar juga rasa takutnya kepada Allah. Rasa takutnya kepada Allah tersebut membuatnya meninggalkan perbuatan maksiat dan mempersiapkan diri untuk bertemu dengan Dzat yang dia takuti. Ayat ini sebagai dalil tentang keutamaan ilmu, karena ilmu akan menumbuhkan rasa takut kepada Allah. Orang-orang yang takut kepada Allah adalah orang-orang yang mendapat kemuliaan-Nya.

\section{Nilai Sosial Budaya}

Mulyakena ing tetamu

Menghormati tamu itu suatu ibadah yang tidak boleh dikurangi nilai ibadahnya, apakah tamunya itu orang kaya atau yang lain. Juga anjuran untuk 
menjamu tamunya dengan apa saja yang ada pada dirinya walaupun sedikit. Menghormati tamu itu dilakukan dengan cara segera menyambutnya dengan wajah senang, perkataan yang baik, dan menghidangkan makanan. Hendaklah ia segera memberi pelayanan yang mudah dilakukannya tanpa memaksakan diri.

Kenane ing hajate wong

Apabila kita mengetahui bahwa sebenarnya kita mampu berbuat sesuatu untuk menolong kesulitan orang lain, maka segeralah lakukan, segeralah beri pertolongan. Terlebih lagi bila orang itu telah memintanya kepada kita. Karena pertolongan yang kita berikan, akan sangat berarti bagi orang yang sedang kesulitan. Cobalah bayangkan, bagaimana rasanya apabila kita berada di posisi orang yang meminta pertolongan pada kita, Dan sungguh Allah SWT sangat mencintai orang yang mau memberikan kebahagiaan kepada orang lain dan menghapuskan kesulitan orang lain.

\section{Yen kaya den luhur}

Bagi mereka yang memperoleh banyak harta harus diamalkan bagi orang yang membutuhkan, sebab islam telah memberi tanggung jawab kepada orang muslim untuk memelihara orang- orang yang membutuhkan karena alasan tertentu tidak bisa memenuhi kebutuhan hidupnya, yaitu melalui zakat, maupun sedekah. Dan islam tidak menganjurkan hidup dari belas kasihan orang lain atau dengan kata lain islam tidak menyukai pengangguran dan mendorong manusia untuk berusaha. Membuka jalan atas dirinya untuk meminta-minta dalam arti kata meminta dengan ketiadaan mudharat maka Allah akan membuka pintu kemiskinan atas dirinya.

\section{Nilai Pancasila}

Ingsun titip tajug lan fakir miskin Ingsun titip tajug (saya menitipkan musholla/masjid). Secara harfiah, sekilas memang dapat diartikan musholla sebagai tempat beribadah umat islam secara kolektif/bersama. Namun jika menelisik lagi ke sisi historis, makna tajug (musholla) bagi masyarakat Cirebon di era jaman Sunan Gunung Jati hidup mempunyai dualisme fungsi, yaitu ; (1) Fungsi keyakinan/agama dan (2) Fungsi Sosial kemasyarakatan, karena masjid/ mushola dijadikan simbol interaksi sosial segala lapisan elemen masyarakat dari berbagai latar belakang. Ada sebuah makna kesetaraan, persamaan hak dan derajat manusia dan penghargaan kehidupan yang bertenggang rasa ketika sebuah aktivitas sosial masyarakat dimulai di masjid. Terlebih lagi dengan latar belakang masyarakat Cirebon yang multi etnik, bahasa dan dialek. ingsun titip fakir miskin bermakna fakir miskin adalah simbol kesinergian hubungan antara sesama manusia. Pesan ingsun titip fakir miskin sesngguhnya dapat dimaknai sebagai pengejawantahan tegaknya nilai kemanusiaan yang bermula dari penghargaan Negara terhadap Warga negaranya, bagiaman penghargaan warga Negara terhadap warga Negara lainnya, karena dasar dari kemanusiaan adalah empati dan simpati. Lakukan prioritas utama mengentaskan kemiskinan, bangkitkan kembali industri rakyat (batik,rotan, dan sebagainya) pertanian, menstabilkan ekonomi kerakyatan, menurunkan harga minyak dan bahan pokok makanan, pendidikan dan kesehatan gratis untuk seluruh warga Negara. Ingsun titip tajug lan fakir miskin adalah khasanah budaya moral masyarakat Cirebon yang harus terus kita pelihara namun jangan salah kaprah dalam memaknainya. Karena dalam untaian kata tersebut memiliki makna yaitu Kesetaraan, Keadilan, Guyub dan yang terakhir dalam menunjang nilai tersebut adalah rasa Kemanusiaan.

\section{Nilai Tujuan Pendidikan Nasional} Aja ilok gawe bobad 
Dusta sangat merugikan diri sendiri dan orang lain. Pendusta dijauhi siapa saja, lantaran orang sama tidak percaya. Kerugian paling fatal bagi pendusta ia tidak akan mendapat hidayah (petunjuk) dari Allah, sehingga sulit menerima kebenaran. Dusta adalah suatu prilaku yang berbentuk ucapan atau perbuatan, baik yang tampak atau yang tersembunyi, yang bertentangan dengan syari'at dan fithroh yang suci. Baturbara (2015: 3) mengungkapkan bahwa kejujuran sebagian dari karakter. Ciri-ciri orang yang memiliki kejujuran yaiu tidak berbohongm tidak mengingkari janji, tidak menipu, serta mengakui kesalahan merupakan dasar pegangan dalam berbuat jujur. Kejujuran dapat dipraktikan dalam kehidupan sehari-hari, baik lingkungan pribadi sendiri, lingkungan keluarga maupun lingkungan sosial. Interaksi sangat menentukan timbulnya suatu kejujuran atau kebohongan dari seorang individu.

\section{Pemanfaatan Nilai Pendidikan Karakter dalam Petatah-Petitih Sunan Gunug Jati untuk pembuatan buku kumpulan Fabel Pembentuk Karakter Positif pada Anak}

Nilai-nilai pendidikan karakter sebagaimana telah disebutkan di atas sangat relevan untuk dijadikan sebagai materi buku pengayaan sastra di SD kelas rendah. Dalam struktur kurikulum 2013 edisi revisi, materi dongeng/ fabel disajikan pada kelas II dan III dengan kompetensi dasar sebagai berikut. (3.8) Menggali informasi dari dongeng binatang (fabel) tentang sikap hidup rukun dari teks lisan dan tulis dengan tujuan untuk kesenangan; (4.8) Menceritakan kembali teks dongeng binatang (fabel) yang menggambarkan sikap hidup rukun yang telah dibaca secara nyaring sebagai bentuk ungkapan diri; (3.8) Menguraikan pesan dalam dongeng yang disajikan secara lisan, tulis, dan visual dengan tujuan untuk kesenangan; (4.8) Memeragakan pesan dalam dongeng sebagai bentuk ungkapan diri menggunakan kosakata baku dan kalimat efektif.

Petatah-petitih Sunan Gunung jati di atas dapat digunakan sebagai materi buku pengayaan berupa kumpulan fabel pembentuk karakter positif yang akan memperkaya nilai pendidikan karakter siswa. Upaya menggunakan bahan bacaan berupa dongeng dan fabel merupakan salah satu langkah internalisasi nilai-nilai pendidikan karakter. Internalisasi pendidikan karakter ini sejalan dengan konsep yang ditawarkan oleh Muhaimin (2008, Hlm. 301) dalam tahap internalisasi pendidikan karakter yang dilakukan dalam tiga tahap, yakni tahap transformasi nilai, tahap transaksi nilai, dan tahap trans-internalisasi.

Tahap transformasi nilai merupakan suatu proses yang dilakukan oleh pendidik dalam menginformasikan nilai-nilai yang baik dan yang kurang baik. Tahap transakis nilai merupakan pemberian pengaruh pada peserta didik melalui contoh nilai yang telah guru jalankan. Tahap trans-internalisasi merupakan tahapan mendalam karena pada tahap ini pendidik harus betul-betul memperhatikan sikap dan perilakunya agar tidak bertentangan dengan apa yang telah diajarkan kepada peserta didik. Hal ini disebabkan adanya kecenderungan siswa untuk meniru apa yang menjadi sikap mental dan kepribadian gurunya.

\section{KESIMPULAN}

Penggabungan dan penyisipan nilainilai pendidikan karakter berdasarkan hasil kajian dari kearifan lokal setempat dapat mendukung pelaksanaan pembelajaran yang bermakna di sekolah. Pada petatah-petitih Sunan Gunung Jati ditemukan nilai-nilai kearifan lokal dan pendidikan karakter yang dapat menumbuhkembangkan wawasan, mental, dan perilaku seseorang. Melalui beragam 
kegiatan literasi yang dapat dilakukan di sekolah, siswa dapat memahami pesan dalam sebuah fabel maupun dongeng sehingga menjadi pijakan dalam berperilaku dan membentuk karakter positif dalam dirinya. Dengan mengkaji dan melestarikan nilai-nilai kearifan lokal melalui kegiatan literasi, diharapkan rasa nasionalisme, kemandirian, dan gotong royong dapat tumbuh dalam diri siswa sejak dini. Harapan untuk dikemudian hari, siswa dapat menjadi generasi yang mampu melestarikan, mengembangkan, dan memanfaatkan potensi kearifan lokal di daerahnya serta mampu menerapkan perilaku sesuai dengan budaya lokalnya, sehingga siswa tidak melupakan identitias dan jati diri bangsa.

\section{DAFTAR PUSTAKA}

Adi Kistoro, Hanif Cahyo, and Aminah Nur Latifa Sibarani. 2020. "Relevansi Konsep Nilai Petatah Petitih Sunan Gunung Djati Dalam Pendidikan Islam.” Jurnal Pendidikan Agama Islam AlThariqah. doi: 10.25299/althariqah.2019.vol4(2).4125.

Arifin, M. (1994). Pedoman Pelaksanaan Bimbingan dan Penyuluhan Agama. Jakarta: PT. Golden Terayon Press.

Batubara, Juliana. (2015). Pengembangan Karakter Jujur melalui Pembiasaan. Jurnal Konseling Pendidikan tersedia online: https://jurnal.konselingindonesia.com/ index.php/jkp/article/view/120/110\#

Asriati, Nuraini. 2012. "Mengembangkan Karakter Peserta Didik Berbasis Kearifan Lokal Melalui Pembelajaran Di Sekolah.” Jurnal Pedidikan Sosiologi Dan Humaniora.

Fajarini, Ulfah. 2014. "PERANAN KEARIFAN LOKAL DALAM PENDIDIKAN KARAKTER." SOSIO DIDAKTIKA: Social Science
Education Journal. doi: 10.15408/sd.v1i2.1225.

Sutrisno, B. H. (2009). Sejarah walisongo Misi Pengislaman di Tanah Jawa. Yogyakarta: Graha Pustaka.

Mastuki HS, \& El-Saha, M. I. (2003). Intelektualisme Pesantren: Potret Tokoh dan Cakrawala Pemikiran di era Pertumbuhan Pesantren. Jakarta: Diva Pustaka.

Muhaimin. (2008). Paradigma Pendidikan Agama Islam. Bandung: PT. Remaja Rosdakarya

Mumpuni, Kristantia Elok. 2013. "Potensi Pendidikan Keunggulan Lokal Berbasis Karakter Dalam Pembelajaran Biologi Di Indonesia." Prosiding Seminar Nasional $X$ Pendidikan Biologi FKIP UNS.

Munir, Miswar. 2013. "Nilai-Nilai Pendidikan Dalam Petatah Petitih Adat Minangkabau (Alternatif Membangun Pendidikan Berkarakter)." Al Hurriyah (Jurnal Hukum Islam).

Narwanti, S. (2014). Pendidikan Karakter. Yogyakarta: Familia.

Nata, Abuddin. (2011). Studi Islam Komprehensif. Jakarta: Kencana.

Pradita, LE, Sumarlam Sumarlam, K. Sadhono, and M. Rohmadi. 2019. "Traditional Expressions As a Reflection of Cirebon Socio-Cultural Life: A Case Study of Petatah-Petitih Sunan Gunung Jati."

Ruyadi, Yadi. 2010. "MODEL PENDIDIKAN KARAKTER BERBASIS KEARIFAN BUDAYA LOKAL (Penelitian Terhadap Masyarakat Adat Kampung Benda Kerep Cirebon Provinsi Jawa Barat Untuk Pengembangan Pendidikan Karakter Di Sekolah)." Proceedings of The 4th International Conference 
on Teacher Education; Join Conference UPI \& UPSI.

Rafiek, M. (2010). Teori Sastra: Kajian Teori dan Praktik. Bandung: PT Refika Aditama.

Rahardjo, U. (2005). Kesusastraan Cirebon (dalam Periodisasi Kuna, Baru, dan Modern). Cirebon: Yayasan Pradipta.

Ramayulis. (2008). Ilmu Pendidikan Islam. Jakarta: Kalam Mulia.

Sjarkawi. (2014). Pembentukan Kepribadian Anak. Jakarta: Bumi Aksara
Syarbini, A. (2016). Pendidikan Karakter Berbasis Keluarga. Yogyakarta: Arruz Media.

Yaumi, M. (2016). Pendidikan Karakter: Landasan, Pilar, dan Implementasi. Jakarta: Kencana.

Yunus, R. 2013. "TRANSFORMASI NILAI-NILAI BUDAYA LOKAL SEBAGAI UPAYA PEMBANGUNAN KARAKTER BANGSA." Jurnal Penelitian Pendidikan UPI. 